\title{
Relevância Provisória e Urgência Sob Medida: Paradoxos Conceituais na Moderna Conjuntura Jurídico-Política Brasileira
}

\author{
Delano David Silva \\ http://lattes.cnpq.br/7210081675639119.ddmsilva@sabesp.com.br \\ Everaldo Luiz Bonfim Fernandez \\ Professor da Universidade Federal do Amazonas desde 1991. Tem experiência na área de Direito, com ênfase em Direito \\ Internacional Público. http://lattes.cnpq.br/2479543824188955. elbf@live.com
}

O presente ensaio visa a observar a definição de pressupostos constitucionais de relevância e urgência nas medidas provisórias sob uma perspectiva sociopolítica. Previstas no artigo 62 da Constituição da República Federativa do Brasil de 1988, são instrumentos de caráter excepcional e de emprego pelo chefe do Poder executivo para editar normas com força de lei para situações de manifesta relevância que exijam urgência. A aferição do cumprimento desses requisitos na realidade, e, consequentemente, o uso adequado deste instrumento normativo, considerado o diagnóstico contumaz de que a competência legislativa do poder Executivo revela-se desvirtuada nesta seara, traduz o núcleo de discussão deste artigo.

Palavras-chave: Constituição. Sociedade. Medidas provisórias. Relevância. Urgência.

PROVISIONAL RELEVANCE AND TAILORED URGENCY:

CONCEPTUAL PARADOXES IN THE MODERN BRAZILIAN JURIDICAL AND POLITICAL CONJUNCTION

ABSTRACT

The present study intends to adjudge the definition of the constitutional presumptions of relevance and urgency in provisional measures under social and political perspectives. Prescribed in Article 62 of the 1988 Constitution of the Federative Republic of Brazil, interim measures are an instrument of exceptionality to be used by the Head of the Executive Branch to edit standards with status of law for situations of relevance which demand urgency. This paper draws attention to the monitoring of compliance with these requisites in the current timeframe and, consequently, the proper use of this normative instrument, considering the contumacious diagnostic that the legislative authority from the Executive Branch of this body is somehow misused as a governmental instrument.

Keywords: Constitution. Society. Provisional measures. Relevance. Urgency. SUMÁRIO

1 Introdução. 2 Iniciação à delineação axiológica das medidas provisórias. 3 Requisitos constitucionais para a devida edição positiva de medidas provisórias. 4 Aproximações teóricas ao significado dos requisitos de relevância e urgência. 5 Considerações finais. 6 Referências.

Recebido em: 26/2/2019

Modificações solicitadas em: 18/10/2019

Aceito em: $21 / 10 / 2020$ 


\section{Humanos e \\ Democracia}

\section{INTRODUÇÃO}

Inspirado no artigo 13 da atual Constituição da República Italiana, o qual dispõe que "em casos excepcionais de necessidade e urgência estritamente definidos por lei, a autoridade de ordem pública poderá adotar medidas provisórias", o poder constituinte do Brasil adotou a medida provisória ${ }^{1}$ na sua tipologia legal com o escopo de atender às demandas sociopolíticas da comunidade brasileira contemporânea, que exige numerosas providências legislativas imediatas em determinadas matérias, cujas circunstâncias graves e excepcionais exigiam a sua participação na produção normativa, sem necessidade de intervenção prévia do poder Legislativo.

Prevista no artigo 62 da Constituição da República Federativa do Brasil de 1988, a MP sucedeu o decreto-lei, porquanto o semantema ditatorial intrínseco a este instrumento deveria ser rechaçado diante da nova ordem jurídica, produto de revoluções burguesas, que da independência da Holanda contra a Espanha no século 16, passando pelas revoluções inglesas seiscentistas, atingiria o apogeu ao término do século $18 \mathrm{com}$ a Independência dos Estados Unidos da América e, máxime, com a excelsa Revolução Francesa.

Nestas circunstâncias, ao emergir como área de legitimação política, o embrião de diversos Estados passou a adotar os fundamentos ideológicos da república e da democracia - hoje patentes na Constituição da República Federativa do Brasil e ajustados ao peculiar cenário sociopolítico nacional.

Isso posto, a partir deste esboço histórico-cultural, o presente ensaio principia com a definição do instrumento normativo que mais suscita debates na presente quadra. Constitui, pois, a MP, em ato normativo primário e excepcional, de competência legislativa autônoma e direta do chefe do poder Executivo Federal, ${ }^{2}$ que pode editá-la com força de lei em situações urgentes e matérias relevantes.

Este tópico, contudo, enfrenta algumas dificuldades para sua delineação no Brasil, principalmente em razão de dissensões doutrinárias acerca da função extraordinária de legislar concedida ao poder Executivo, que se comporta como exceção à função típica legiferante inerente ao poder Legislativo, e se agrava pelo desmedido número de medidas provisórias já editadas pelo Executivo, ainda que aparentemente excepcionais.

\section{INICIAÇÃO À DELINEAÇÃO AXIOLÓGICA DAS MEDIDAS PROVISÓRIAS}

Mesmo após vivenciar uma ditadura militar marcada por autoritarismo exasperado e nacionalismo exacerbado, que governou o Brasil por mais de 20 anos, admite-se hoje que a pessoa ocupante do cargo de presidente da República, de forma discricionária, por meio de um ato normativo, edite uma MP de imediato para o emprego em circunstâncias peculiares, após a devida submissão de tal ato normativo ao Congresso Nacional.

A partir dessa leitura do texto constitucional, tem-se a exigência de dois requisitos fundamentais para edição de MP: relevância e urgência. As medidas provisórias, portanto, apenas poderão ser editadas em caráter excepcional quando houver relevância e urgência.

\footnotetext{
Para garantir a fluidez textual, adotar-se-á a sigla MP para a designação desta espécie normativa.

2 Os chefes do poder Executivo dos Estados Federados podem valer-se das medidas provisórias, caso esteja prevista esta possibilidade em suas respectivas Constituições Estaduais; entretanto isto não constitui o foco de estudo deste ensaio.
} 
Relevância e urgência são, todavia, conceitos jurídicos indeterminados, e, por essa razão, não suscetíveis de identificação imediata. Especialmente por serem concebidos como genéricos e subjetivos, há certa dificuldade na sua aferição, configurando tal abertura uma das hipóteses para justificar a demasiada edição de medidas provisórias.

Pautada no sistema de colaboração entre os poderes, a Constituição Federal exige que o chefe do poder Executivo, após a edição preliminar de uma MP, submeta-a de imediato ao Congresso Nacional para que este realize o controle de seus pressupostos. Ora, o poder Legislativo poderá rejeitar medidas provisórias que não contemplem os referidos requisitos de admissibilidade, ou seja, que não sejam relevantes e urgentes.

Conforme fonte obtida nos sites da Câmara dos Deputados, Senado Federal e Portal da Legislação do Governo Federal (2015, p. 3), o ex-presidente Luiz Inácio Lula da Silva editou 419 medidas provisórias durante os oito anos de governo, uma média de 4,3 MP por mês.

Por sua vez, Dilma Vana Rousseff editou 145 medidas provisórias durante seu primeiro ano de mandato (2011-2014), totalizando-se uma média de 3 por mês durante o exercício de suas funções governamentais.

A Constituição da República Federativa do Brasil de 1988 é o basal ordenamento jurídico-normativo, servindo de modelo em âmbitos nacional, estadual, distrital e municipal para que os entes federativos atuem em consonância com os seus ditames, evitando, assim, lacunas, discrepâncias ou antagonismos na aplicação de princípios e normas jurídicas e na atuação dos diversos órgãos estatais.

Nesse sentido, a fim de se propiciar uma atuação equilibrada dos órgãos nos entes federativos, infere-se a previsão do princípio da simetria, o qual, embora não esteja grafado expressamente no texto constitucional, é amplamente construído a partir do diálogo entre outros elementos constitucionais - isonomia, proporcionalidade, supremacia constitucional, devido processo legal, razoabilidade e boa-fé.

Em razão da constatação da grande e crescente frequência das medidas provisórias na pauta do Legislativo federal ${ }^{3}$ e, por vezes, do Legislativo estadual, que não observam tais pressupostos constitucionais, esta pesquisa tecerá as diretrizes para orientar as noções dos pressupostos constitucionais sobreditos.

\section{REQUISITOS CONSTITUCIONAIS PARA A DEVIDA EDIÇÃO POSITIVA DE MEDIDAS PROVISÓRIAS}

No âmbito federal, uma vez adotada a MP, deve o presidente da República submetê-la de imediato à análise do Congresso Nacional. Caso seja editada durante o recesso parlamentar, que ocorre, em regra, no período de 22 de dezembro a 2 de fevereiro e de 17 de julho a 1 o de agosto, a contagem do prazo ficará suspensa, iniciando-se no primeiro dia da sessão legislativa seguinte (CLÈVE, 2011, p. 229).

\footnotetext{
Nesse sentido, a título de exemplo, informação obtida no site do Senado Federal, com o seguinte teor: "O Senado recebeu nesta segunda-feira (26) três medidas provisórias aprovadas pela Câmara na última semana. Com isso, passa a seis o número de medidas que trancam a pauta do plenário e impedem a votação de projetos de lei. Todas precisam ser aprovadas até o dia 2 de junho para que não percam a validade" (BRASIL, 2015, p. 1).
} 


\section{Humanos e \\ Democracia}

De acordo com o artigo 62, §§ 5o e 9o da CF, e artigo 5 da Resolução no 1/2002 do Congresso Nacional, uma vez recebida a MP pelo Congresso Nacional, esta será enviada a uma Comissão Mista composta de deputados e senadores, que deverá examinar a medida provisória e sobre ela emitir parecer no prazo improrrogável de 14 dias, contados da publicação do ato no Diário Oficial da União. Este parecer deverá apreciar os aspectos constitucionais e de mérito, a matéria, a adequação financeira e orçamentária, a observância aos pressupostos de relevância e urgência, e o cumprimento pelo presidente da República do disposto no artigo 2ㅇ, §1으 da Resolução no 1/2002-CN, que exige deste o envio de seu texto ao Congresso Nacional, acompanhado de documento expondo a motivação fundamentada do ato no mesmo dia da publicação da MP no DOU (CLÈVE, 2011, p. 235).

Caso a Comissão não emita o parecer no prazo estabelecido, caberá à Câmara dos Deputados apreciar a MP (artigo 6으, §1으), sendo possível que o Relator da Comissão Mista profira parecer no Plenário da Câmara ( $2^{\circ}$ ) $)$. Tal apreciação pela Comissão é indispensável, pois se trata de uma exigência constitucional; todavia, "a possibilidade de atuação apenas do Relator gerou acomodação no Parlamento e ineficácia da Comissão Mista" (CLÈVE, 2011, p. 233).

Após o parecer da Comissão Mista, a MP será apreciada pelo plenário de cada uma das Casas. O processo de votação será em sessão separada, tendo início na Câmara dos Deputados para deliberação principal e primeira votação, com a Casa revisora sendo o Senado Federal. Aprovada na Câmara por maioria simples de votos, a medida provisória será enviada para o Senado, que, na revisão, verificará preliminarmente o atendimento ou não dos pressupostos constitucionais de relevância e urgência e a sua adequação financeira e orçamentária (artigo 8 o da Resolução n. 1/2002-CN), e, no caso de atendidos esses requisitos, será então realizada a análise de seu mérito.

Sendo aprovada integralmente por, pelo menos, a maioria simples do Senado, a MP será convertida em lei e promulgada pelo presidente do Senado, que a remeterá ao presidente da República para que este a publique como ato normativo primário.

Do contrário, dentro do prazo de vigência, poderão dar-se três situações: aprovação com alterações, rejeição expressa ou rejeição tácita.

Tanto a Câmara dos Deputados quanto o Senado Federal podem apresentar emendas supressivas ou aditivas ao conteúdo da medida provisória, desde que não tratem de matéria diferente daquela disposta no texto da MP.

Nesse caso, sendo a MP aprovada com emenda, isto é, com qualquer alteração no texto da medida pelo Congresso, transformar-se-á em um projeto de lei de conversão (Resolução no 1 de 2002-CN, artigo 5o, §4으, inciso I).

De maneira diversa, pode a MP editada ser rejeitada expressamente, situação em que será arquivada e perderá seus efeitos de forma retroativa.

O prazo para apreciação da medida provisória no Congresso Nacional é de 60 dias contados da sua publicação no Diário Oficial. Findos os primeiros 60 dias, o prazo é prorrogável uma única vez por igual período, caso não tenha sido encerrada a votação nas duas Casas do Congresso Nacional. 
Totalizado o prazo de 120 dias, caso não seja convertida em lei pelas Casas do Congresso, a MP perderá a eficácia desde a sua edição (artigo 62, §3ํ, da CF/1988), devendo o Congresso Nacional disciplinar, por decreto legislativo, as relações jurídicas dela decorrentes (rejeição tácita).

Importante ressaltar que o artigo 62, §6ํ, CF/1988 dispõe que, não sendo a medida provisória apreciada em até 45 dias pelo Congresso Nacional, contados de sua publicação, entrará em regime de urgência constitucional.

Isso significa que haverá sobrestamento da pauta, ou seja, ocorrerá o trancamento da pauta na casa legislativa em que a MP esteja tramitando, de modo que, em sessão ordinária, nenhuma proposição poderá ser deliberada até concluída a votação desta MP.

Importante observar que se trata de dois prazos diferentes, mas paralelos e interdependentes (prazo de vigência de 60 dias prorrogáveis por mais 60 dias e prazo de trancamento de pauta do Congresso, que corresponde a 45 dias), muito embora tenham ambos como termo inicial a edição da MP.

A Carta Política de 1988 determina que, para a edição de medidas provisórias, há de ser observado o cumprimento de dois pressupostos: urgência e relevância.

Assim, é necessária a presença simultânea dos dois requisitos para que sua adoção seja autorizada; caso contrário, estar-se-á diante de uma inconstitucionalidade.

Tais pressupostos dignam-se a limitar o uso de MP apenas para situações ditas urgentes e relevantes, justamente por ser excepcionalidade a ser utilizada pelo chefe do poder Executivo, e de exceção à função típica legiferante do poder Legislativo.

Ocorre que a Lei Maior, muito embora tenha adotado os referidos pressupostos, não tratou de delimitá-los, dificultando a sua apreciação.

Diante do silêncio, relevância e urgência foram caracterizadas como termos abstratos em decorrência da fluidez linguística.

Reitera-se que são conceitos jurídicos indeterminados, porque não são passíveis de identificação imediata, necessitando de interpretação por parte do seu aplicador. Ao não determinar quais seriam as situações relevantes e urgentes, o Constituinte concedeu a esses requisitos caráter de "cláusulas abertas", e, pois, passíveis de interpretações variadas ao longo do tempo e do espaço, o que conferiu uma maior liberdade aos chefes do Executivo na edição de medidas provisórias, que se "beneficiam", com bastante frequência, dessa abertura do legislador para aplicar seus próprios critérios e editar medidas provisórias que, muitas vezes, não observam os pressupostos exigidos.

Obviamente, os vocábulos "relevância" e "urgência" são portadores de conteúdo de significação ampla, sujeitos a critérios axiológicos cambiantes, que lhes dão timbre subjetivo de fungibilidade, instabilidade e volubilidade.

Apesar dessa aparente insegurança, entretanto, Alexandre de Moraes $(2015$, p. 95$)$ alerta que a não explicação dos pressupostos pela Constituição Nacional é uma técnica ideológica por trazer consigo desígnio intencional, no qual o legislador constitucional introduz "expressões indeterminadas ou imprecisas, como relevância e urgência, a fim de que, em cada momento propício à edição de medidas provisórias, eles possam sofrer uma valoração, adequando-se aos fatos que poderão servir de fundamento a essas medidas". 


\section{Humanos e \\ Democracia}

Com o intuito de preservar a permanência duradoura da Lei das Leis, de maneira que sua interpretação permita a adaptabilidade dos preceitos de acordo com o tempo e espaço, a impossibilidade de previsão pelo legislador de todas as circunstâncias que recobrem um dado instrumento foi empregada na Constituição da República de 1988.

Embora sejam cláusulas abertas e gerais, inaplicável ao intérprete a prerrogativa de atribuir aos conceitos qualquer significado.

De acordo com os esclarecimentos Celso Antônio Bandeira de Mello (2018, p. 100), "a circunstância de relevância e urgência serem, como efetivamente o são, conceitos 'vagos', 'fluidos', 'imprecisos', não implica que Ihes faleça densidade significativa”, ou seja, apesar de que possam ser considerados conceitos indeterminados, são passíveis de identificação plena. De fato, todo conceito jurídico indeterminado é portador de um comando e, portanto, de um conteúdo, ainda que esta relação de linearidade não se manifeste de modo incontestável em precipitada apreciação.

Em observância à factibilidade de conceitos jurídicos indeterminados, a valoração da presença dos requisitos e do seu teor, "acarreta um juízo discricionário por parte de seu destinatário final imediato" (FERRAZ JÚNIOR, 2010, p. 143-144), i.e., o chefe do poder Executivo. Mesmo impreciso, o conceito deve apresentar uma diretriz em que se aloja o seu significado. Desse modo, apesar de a Constituição da República Federativa do Brasil de 1988 não explicitar as situações que configurariam relevância e urgência, a doutrina tratou de identificá-las, levando-se em consideração todo o contexto que envolve o referido instrumento desde a sua criação pelo legislador, principalmente porque a penumbra da subjetividade dos termos abre margem para a utilização desmedida e indevida de MP.

Passa-se, portanto, à pressurosa apreciação de parte do incomensurável arcabouço doutrinário atinente aos dois elementos de constitucionalidade das medidas provisórias na condição de espécies legislativas excepcionais.

\section{APROXIMAÇÕES TEÓRICAS AO SIGNIFICADO DOS REQUISITOS DE RELEVÂNCIA E URGÊNCIA}

O artigo 62 da Constituição da República estabelece como requisitos para a edição de medidas provisórias a presença simultânea dos pressupostos constitucionais urgência e relevância. Diante dessa exigência, impõe-se definir o conteúdo semântico dos termos, sem os quais não há como identificar as hipóteses possíveis de serem agasalhadas pela MP.

Para Celso Antônio Bandeira de Mello, "a doutrina chama-os de pressupostos, por serem elementos que deverão ser considerados em uma fase antecedente à sua própria edição" (2018, p. 99).

Relevância pode ser entendida como todo trecho material da realidade social que é importante, necessário, fundamental e pertinente à vida em sociedade.

O conceito de relevância está absolutamente atrelado ao interesse público. Destarte, o conceito era inclusive utilizado à época do extinto decreto-lei da Constituição Federal de 1967, que dispunha em seu artigo 55 que o presidente da República poderia expedir decretos-lei em casos de urgência ou interesse público relevante. 
Não é todo e qualquer interesse público, contudo, que enseja a edição de medidas provisórias. Estas são destinadas aos casos mais importantes, mais graves, que demandam atuação imediata do Estado Federal. As medidas provisórias, portanto, como explica Uadi Lammêgo Bulos (2016, p. 181-182), servem "para suprir ou amenizar - momentaneamente situações de enorme risco e gravidade reconhecida". Aduz o jurisconsulto:

Etimologicamente o vocábulo relevância, advindo de relevare, traduz importância social, vantagem de algum empreendimento, ato de fazer ressaltar, o que significa valorar o fato a ser considerado como desencadeador de uma medida provisória $(2016$, p. 182).

A relevância mencionada no artigo 62 da Constituição Nacional é a providência que se impõe, em determinada situação, para tutelar interesse público, cujas peculiaridades e especificidades da matéria que veicula reclamam atenção e atuação extraordinárias por parte do Estado. O fim será alcançado por meio da MP, inexistindo outro instrumento hábil a fazê-lo.

A relevância, pois, é "extraordinária, excepcional, especialmente qualificada e contaminada pela contingência, acidentalidade e imprevisibilidade" (CLÈVE, 2011, p. 89). Nesse sentido, sua adoção inadmite satisfação de interesses outros que não os da sociedade.

A relevância deve vincular-se, unicamente, à realização do interesse público sob apreciação. Esta relevância que autoriza deflagração da competência normativa do chefe do poder Executivo em questão não se confunde com a ordinária, desafiadora do processo legislativo comum. Trata-se, na verdade, de uma relevância extraordinária, excepcional, especialmente qualificada, socialmente adjetivada, contaminada pela quota circunstancial, acidentalidade e imprevisibilidade (CLÈVE, 2011, p. 89-90).

Ora, a relevância para a sociedade já justificaria a adoção do ato normativo por parte do poder Executivo, contanto que não implique a satisfação de interesses particulares, sob o risco de resultar em sérios comprometimentos da ordem pública.

Ainda acerca da relevância, destaca-se a explanação de que "a relevância de que trata a Constituição não é, apenas, da matéria tratada, devendo qualificar a situação a qual enseja (estado de necessidade) a medida provisória" (CLÈVE, 2011, p. 173).

Ora, além de relevante a matéria, a situação também deve ser urgente. A esse respeito, de acordo com o ministro Celso de Mello, em seu voto na ADI 221-MC (BRASIL, 2015), a justificativa da edição da MP está na existência de um estado de necessidade que demanda uma rápida atitude do chefe do Executivo:

O que justifica a edição dessa espécie normativa, com força de lei, em nosso Direito Constitucional, é a existência de um estado de necessidade, que impõe ao poder público a adoção imediata de providências de caráter legislativo, inalcançáveis segundo as regras ordinárias de legiferação em face do próprio periculun in mora que fatalmente decorreria do atraso na concretização da postação legislativa (...). É inquestionável que as MPs traduzem, no plano de organização do Estado e na esfera das relações institucionais entre os poderes Executivo e Legislativo, um instrumento de uso excepcional (Voto do Min. Celso de Mello, no julgamento da ADI 221-MC, Plenário, DJ de 22-10-1993). 


\section{Democracia}

Humanos e

Conforme explica a ministra Carmem Lúcia, citada por Clève (2011, p. 174), o artigo 62 da Constituição deve ser lido do seguinte modo: "em caso de relevância e quando esse caso de relevância for urgente [...]". A urgência significa que a MP deve regular uma situação que não suporte aguardar um período prolongado.

O contexto fático que requer a edição da medida deve ser iminente e inadiável, aliando a questão de data (momento) à condição social nela constatada (CLÈVE, 2011, p. 68-71). A urgência, então, admite maior precisão conceitual e é mais fácil de ser compreendida, podendo ser interpretada como aquilo que exige prioridade e que demanda, além de uma providência legislativa imediata, uma eficácia também imediata, inalcançável pelas regras ordinárias de legiferação, por indicar um perigo de dano, uma emergência, uma situação crítica ou muito grave, um estado de necessidade legislativa. Assim esclareceu o ministro Celso de Mello na ADI 221-MC. Neste mesmo sentido, Celso Antônio de Mello, ipsis litteris:

[...] mesmo que a palavra contenha em si algum teor de fluidez, qualquer pessoa entenderá que só é urgente o que tem de ser enfrentado imediatamente, o que não pode aguardar o decurso do tempo, caso contrário o benefício pretendido inalcançável ou o dano que se quer evitar consumar-se-á ou, no mínimo existirão sérios riscos de que sobrevenham efeitos desastrosos em caso de demora (2018, p. 118).

Assim, a urgência referida na Constituição da República de 1988 consubstancia-se em uma hipótese que requer positivação premente, não sendo possível aguardar o tempo necessário do processo legislativo ordinário, nem mesmo se socorrendo da alegação de urgência no trâmite, facultada no artigo 64, $\S \S 1$ e 2 ㅇ da Lei Maior, sob pena de ocasionar riscos ou danos à coletividade.

Ora, situações de emergência podem existir e a MP surge como uma necessidade a fim de superar, como bem lembra Gustavo Zagrebelsky (apud CLÈVE, 2011, p. 22), "a lentidão procedimental e política, nem sempre evitáveis em sede parlamentar". Constitui demanda inadiável, em que tanto o processo legislativo ordinário e o sumário abreviado são ineficazes. Isto já possui relativo consenso na doutrina brasileira, conforme Balera assim se manifesta sobre o pressuposto da urgência:

[...] só há urgência, a autorizar a edição de medidas provisórias, quando, comprovadamente, inexistir tempo hábil para que uma dada matéria, sem grandes inilidíveis prejuízos à Nação venha a ser disciplina por meio de lei ordinária. Ora, é perfeitamente possível, nos termos dos $\S \S 10$ e $2 \circ$ do art. 64 da CF, aprovar-se uma lei ordinária no prazo de 45 dias contados da apresentação do projeto. Logo, em nosso Direito Positivo só há urgência se realmente não se puder aguardar 45 dias para que uma lei ordinária venha a ser aprovada, regulando o assunto $(2009$, p. 16).

A configuração do requisito da urgência, por ser uma cláusula aberta, dificulta predeterminar seu significado, e por esse motivo há de ser verificada diante do caso concreto. À vista disso, justifica-se a obrigação do chefe do Executivo de apresentar a circunstância que embasou a necessidade de edição daquele instrumento normativo.

Para Balera (2009), as medidas provisórias assemelham-se a um procedimento cautelar, que se antecipa ao processo legislativo. Assim, para esta autora, o pressuposto urgência insere-se no periculum in mora, "visto que, em determinada matéria, objeto de medida pro- 
visória, a espera do trâmite normal do processo legislativo pode inviabilizar o caráter acautelatório do instrumento constitucional, causando um dano irreparável ou de difícil reparação" (2009, p. 17).

O pressuposto da relevância, por sua vez, pode ser compreendido como o fumus boni iuris, por se entender que os motivos causadores da emanação das medidas provisórias "devem ser altamente significativos em termos de premência, para que se configure a necessidade deste ato normativo no exercício da ação executiva" (BALERA, 2009, p. 18-19). Assim, é indispensável a prova da existência daquela situação urgente, cujos motivos devem ter alto grau de importância (relevância) que se vinculem unicamente à realização do interesse público.

Segundo entendimento de Bulos (2016, p. 1.188), deve-se explorar a certeza positiva e a certeza negativa como instrumentos aptos a penetrar a zona de penumbra na qual tais expressões, relevante e urgente, inserem-se.

Assim, elencar as matérias de induvidosa incidência corresponde à certeza positiva, por exemplo, das matérias não vedadas pela Constituição.

Na mesma proporção, está em se identificar a certeza negativa, ou seja, as situações das MPs que ultrapassam os pressupostos de autorização, como o chefe do Executivo dispor sobre matéria que não seja de sua competência ou a qual puder sofrer o processo legislativo normal embora relevante, mas não urgente.

O conceito de relevância, conforme exposto, é mais movediço e difícil de determinar empiricamente, enquanto o pressuposto da urgência possui um significado mais objetivo e inteligível, embora comporte certa margem de indeterminação.

Diante da imprecisão terminológica dos termos, a doutrina pátria tratou de interpretar juridicamente os conceitos de relevância e urgência. Percebe-se, todavia, que o espaço de atuação para quem deverá criar uma MP é gigantesco, pois não estão definidas na Lei Maior quais as situações que poderão ser consideradas urgentes e relevantes, fazendo-se importantíssima a regulação desse instituto.

Assim, relativamente aos conceitos jurídicos indeterminados, os doutrinadores têm apresentado posições divergentes quanto à admissibilidade de sua discricionariedade. Os argumentos conflitantes dividem-se em duas grandes correntes: de um lado, há aqueles que objetivam justificar a relação entre conceitos indeterminados e discricionariedade com o fim de garantir a liberdade do administrador diante da vagueza conceitual; e de outro, os que fazem uma distinção entre os termos com o fito de buscar vinculação para uma única decisão justa (BULOS, 2016, p. 1.189).

Em certas situações o legislador, ao elaborar suas leis, usa de pouca densidade reguladora, com o objetivo de conceder maior espaço de atuação para a administração pública, o que não significa, necessariamente, maior discricionariedade.

Nesse cenário, para alguns doutrinadores conceitos jurídicos indeterminados e discricionariedade conectam-se na medida em que os textos legais trazem conceitos abertos, vagos e indefinidos, permitindo à administração maior independência na escolha nas decisões de solução do caso concreto. 


\section{Democracia}

Conceitos indeterminados e discricionariedade são fenômenos interligados, visto que, muitas vezes, o órgão administrativo deve lançar mão desta para poder preencher aqueles. A discricionariedade é, no conceito de Hely Lopes Meirelles (2017, p. 143), "a liberdade de agir dentro dos limites legais". Para Maria Sylvia Zanella Di Pietro (2019, p. 276) a discricionariedade "ainda pode dizer respeito a uma escolha entre o agir e não agir", ou seja, também existe discricionariedade quando o administrador público tem a "possibilidade de escolher entre atuar ou não".

Observando esses conceitos, o chefe do Executivo age com discricionariedade ao editar medidas provisórias, porque possui liberdade na escolha de lançar mão ou não do instrumento, muito embora esteja vinculado aos pressupostos constitucionais de relevância e urgência. Isso significa que, apesar da liberdade que lhe é conferida, o chefe do Executivo possui limites que a lei impõe à sua atividade.

A lei, entretanto, define o motivo e a finalidade para editar medidas provisórias, que são a ocorrência dos pressupostos constitucionais, utilizando-se noções vagas e imprecisas, bem como vocábulos plurissignificativos, os chamados conceitos jurídicos indeterminados, "que deixam à administração a possibilidade de apreciação segundo critérios de oportunidade e conveniência administrativa" (DI PIETRO, 2019, p. 278).

Assim, a lei autoriza o chefe do Executivo utilizar o instrumento da MP nos casos de "relevância" e "urgência", mas sem definir em que consistem os conceitos.

Segundo entendimento de Maria Sylvia Zanella Di Pietro (2019, p. 281), nessas situações em que "a lei não estabelece critérios objetivos que permitam interferir quando tais fins são alcançados, haverá discricionariedade administrativa". Como a lei não é suficientemente capaz de pormenorizar todas as condutas, muito embora busque definir alguns limites para atuação do agente administrativo, a própria lei em algumas situações oferece a esse agente a possibilidade de valoração da conduta.

Eis que se situa o poder discricionário, nos casos em que "pode o agente avaliar a conveniência e oportunidade dos atos que vai praticar na qualidade de administrador dos interesses coletivos" (DI PIETRO, 2019, p. 282).

O poder discricionário é uma prerrogativa conferida ao chefe do poder Executivo para edição de medidas provisórias concretizada no momento em que o ato de editar uma MP é praticado. Hely Lopes Meireles (2017, p. 149), porém, alerta que essa liberdade de escolha "deve se conformar com o fim colimado na lei", sob pena de "não ser atendido o objetivo público da ação administrativa".

A discricionariedade é, portanto, a margem de liberdade conferida pela lei ao agente público para que este encontre a solução mais adequada para o caso concreto e exerça suas competências, considerando as variáveis de conveniência e oportunidade. Tal ato, no caso das medidas provisórias, é ainda caracterizado pela existência de conceitos jurídicos indeterminados, os quais arvoram o Executivo, para além do poder discricionário descrito, da competência de apurar a relevância e urgência em dado contexto. 
Há, neste sentido, a ocorrência de uma dupla valoração por parte do administrador: 1) interpretar o contexto a fim de avaliar se é caso a justificativa da edição de medidas provisórias, presentes relevância e urgência e, 2) sendo este o caso, exercer a faculdade de editá-las, nos termos da Constituição.

Os conceitos jurídicos indeterminados são expressões fluidas, imprecisas, contidas em normas jurídicas que necessitam de interpretação e avaliação para alcançar a seu exato conteúdo e sentido (MEIRELLES, 2017, p. 144-145). A definição dos conceitos jurídicos indeterminados é quase unânime entre os autores. Por esse motivo, utiliza-se a definição apresentada por Maria Sylvia Zanella Di Pietro, segundo a qual:

A expressão conceitos jurídicos indeterminados, embora bastante criticável, ficou consagrada na doutrina de vários países, como Alemanha, Itália, Portugal, Espanha e, mais recentemente, no Brasil, sendo empregada para designar vocábulos ou expressões que não têm sentido preciso, objetivo, determinado, mas que são encontrados com grande frequência nas normas jurídicas dos vários ramos do Direito (2019, p. 97).

Os conceitos jurídicos determinados, como o próprio nome sugere, são conceitos mais objetivos e cujo conteúdo, senão inequívoco, pode ser facilmente definido e estabelecido pela própria experiência comum ou por meio de recursos científicos (FERRAZ JÚNIOR, 2010, p. 184).

Os conceitos jurídicos indeterminados, ao contrário, carecem de precisão e exigem uma atividade interpretativa para apuração da sua expressão e alcance. Partindo-se para a análise dos requisitos de relevância e urgência, constatar-se-á que são conceitos jurídicos com significados abertos e possibilidade de múltiplas interpretações, posto que os limites desses conceitos não foram traçados com exatidão pela lei, ficando a cargo do aplicador a sua determinação e complementação de acordo com o caso concreto. Embora pressupostos constitucionais das medidas provisórias sejam indeterminados, uma vez que possuem um "campo amplo de significação necessitando de uma atividade interpretativa para se obter o seu real sentido" (TOURINHO, 2008, p. 2), está o chefe do Executivo autorizado a, no que lhe couber, utilizar de seu poder discricionário, conforme a conveniência e oportunidade requeridas pela situação, para editar tal ato normativo.

Em verdade, a grande dificuldade em admitir a relação entre discricionariedade e conceitos jurídicos indeterminados aloja-se na possibilidade ou não de análise pelo Judiciário dos atos administrativos discricionários. Faz-se, então, oportuno destacar que o Supremo Tribunal Federal já se manifestou pela imperiosa necessidade de haver o controle jurisdicional da discricionariedade dos atos emanados do poder público.

O STF tem se posicionado no sentido de que não se exime o poder Judiciário de analisar se a solução adotada pelo administrador público é a mais adequada para o caso concreto em caso de existência de conceitos jurídicos indeterminados, ainda que possa conferir algum grau de discricionariedade (ADI 162/DF, RTJ 145/101, RTJ 165/174).

A edição de medidas provisórias, pelo presidente da República, para legitimar-se juridicamente, depende, dentre outros requisitos, da estrita observância dos pressupostos constitucionais da urgência e da relevância (CF, art. 62,"caput"). - Os pressupostos da urgência e da relevância, embora conceitos jurídicos relativamente indeterminados e fluidos, mesmo expondo-se, inicialmente, à avaliação discricionária do presidente da República, estão 


\section{Democracia}

Humanos e

sujeitos, ainda que excepcionalmente, ao controle do poder Judiciário, porque compõem a própria estrutura constitucional que disciplina as medidas provisórias, qualificando-se como requisitos legitimadores e juridicamente condicionantes do exercício, pelo chefe do poder Executivo, da competência normativa primária que Ihe foi outorgada, extraordinariamente, pela Constituição da República. Doutrina. Precedentes (STF, ADI-MC 2213/DF, Rel. Min. Celso de Mello, DJ 04/04/2002) (grifo nosso).

Percebe-se, primeiramente, que o vínculo entre conceitos jurídicos indeterminados e discricionariedade é confirmado pelo Supremo Tribunal Federal, isto é, não sendo o caso de motivo relevante e urgente a ensejar a edição de MP, também não será a hipótese de ato conveniente e oportuno a sua criação.

Com relação ao ato discricionário, contudo, o poder Judiciário poderá contemplar aspectos concernentes à legalidade e verificar se a administração pública não ultrapassou os limites da discricionariedade.

Assim, sempre que o ato administrativo discricionário ofender os limites "estabelecidos ao juízo de conveniência (objeto) e oportunidade (motivo), principalmente os princípios que regem a atividade administrativa, desvirtuando a finalidade prevista na norma ou utilizando-se de meio inadequado para sua consecução deverá ser controlado pelo Judiciário" (TOURINHO, 2008, p. 4).

No caso das medidas provisórias, o chefe do Executivo tem discricionariedade tanto na edição de MP quanto na análise dos pressupostos de relevância e urgência, no sentido de decidir se há ou não a ocorrência dos pressupostos naquele caso concreto.

Para ambas as situações exige-se uma interpretação dos fatos, em que um é consequência do outro. Como há fluidez nos conceitos (o que são), haverá margem na determinação da ocorrência destes (se é o caso de).

Diante de conceitos vagos e imprecisos, torna-se mais difícil exigir da administração pública a melhor resposta para determinada situação que não possui parâmetro objetivo fixado. Discricionariedade não significa arbitrariedade: implica agir com liberdade de opção, decisão e ação, mas dentro de parâmetros jurídicos.

De qualquer maneira, posteriormente, o poder Legislativo avaliará o cumprimento desses pressupostos e deverá conferir se a administração se manteve no campo significativo da aplicação da regra ou não. Esse controle é possível, porque as escolhas da administração não são inteiramente livres.

O chefe do Executivo, embora tenha certa margem de liberdade para escolher a meIhor solução a ser adotada no caso concreto, está limitado ao princípio da legalidade e pela existência de razoabilidade e motivação (DI PIETRO, 2019, p. 227). Não observado esse limite, poderá o poder Legislativo sustar os efeitos da MP irregularmente editada.

Assim, apesar do poder dirigido ao chefe do poder Executivo, ao qual compete, dentro de um juízo de discricionariedade, envolto de um caráter político, exercer o direito de editar MP, esta está sujeita ao controle pelo poder Legislativo, o qual pode e deve apreciar e valorar os requisitos constitucionais indeterminados de relevância e urgência para evitar arbitrariedades, e também pelo poder Judiciário. 
Justamente a falta desse controle, sobretudo por parte do poder Legislativo, enseja a proliferação de medidas provisórias sem nenhuma relevância ou urgência, banalizando o instituto primário do âmbito federal.

Levando-se em conta os aspectos trazidos à baila, filia-se este estudo à corrente que entende os conceitos jurídicos indeterminados como, pelo menos neste caso específico, postulados amplamente relacionados com a discricionariedade.

Conceitos jurídicos indeterminados que ensejam ou não discricionariedades, de qualquer forma, submetem-se a controle jurisdicional. Ademais, o poder Legislativo possui amplo poder e responsabilidade no controle sobre a decisão do chefe do poder Executivo em valorar urgência e relevância referentes à edição de medidas provisórias, o que deveria explicitar um eficiente e eficaz sistema de freios e contrapesos.

\section{CONSIDERAÇÕES FINAIS}

A medida provisória perfaz-se como instrumento precário e possui lapso temporal definido, o que exige a transformação da MP em lei pelo poder Legislativo no prazo de até 120 dias, sob risco de perder eficácia e ter seus efeitos futuros cessados, se revogada.

Para que o seu conteúdo opere com vigência para além do caráter provisório, é necessário que a MP seja convertida em lei ordinária, ato que somente se completa com a atuação conjunta dos poderes Executivo e Legislativo.

A primeira avaliação da existência dos pressupostos constitucionais de urgência e relevância para efeito da edição da medida provisória é realizada pelo chefe do poder Executivo. Posteriormente, cabe ao poder Legislativo analisar se a medida editada obedece aos preceitos constitucionais, ou seja, tem a incumbência de julgar se os pressupostos de urgência e relevância foram preenchidos pelo titular do Executivo.

Cabe afirmar, portanto, que na esfera legislativa opera-se uma sobreposição do juízo anteriormente realizado pelo chefe do poder Executivo, em consonância com a dinâmica de cooperação e tripartição dos poderes da República.

Constata-se, no entanto, uma ineficiência no controle das medidas provisórias pelo poder Legislativo. A partir de mera observação do quadro legislativo dos mandatos dos últimos dois chefes do poder Executivo Federal, percebe-se uma desmesurada edição de medidas provisórias, ficando a inconstitucionalidade formal muito clara, tendo em vista o flagrante desrespeito ao artigo 42, parágrafo 1ำ, porquanto a avaliação quanto à urgência e relevância simplesmente não é realizada; caso contrário, uma grande parte destas medidas provisórias teria sido rejeitada. Relevância e urgência devem ser vislumbradas, a fim de que não se abra margem para MP sem observação dos seus pressupostos.

Diferentemente do que previu a Constituição Federal de 1988, a medida provisória está longe de ser ato excepcional. É notória a necessidade de um conjunto normativo consistente, coerente e, sobretudo, eficaz, com objetivo de obter uma maior racionalização do processo legislativo e pôr fim à utilização casuística das medidas provisórias pelo chefe do Executivo e sua conversão em lei sem critérios pelo poder Legislativo. 


\section{Democracia}

Humanos e

Medidas provisórias, portanto, devem ser concatenadas a três requisitos principais: relevância, urgência e excepcionalidade. Firmou-se neste estudo que relevância pode ser entendida como aquilo cuja importância é necessária ao interesse público e a urgência se traduz em uma situação inadiável que exige uma providência imediata, não podendo aguardar o processo legislativo ordinário sem prejudicar excessivamente o que se pretende alcançar. Com relação à urgência, trata-se de satisfação imediata de interesse coletivo que jamais poderia esperar o processo legislativo comum. Quanto à excepcionalidade, destina-se a situações que exijam uma rápida atuação do Estado, casos em que a demora do processo legislativo prejudicaria excessivamente o desígnio social que se pretende.

Apesar da obrigatória dimensão jurídica, o ensejo político prevalece fomentando a conversão em lei de inúmeras medidas provisórias com a chancela do Congresso Nacional, em âmbito federal, e de várias Assembleias Legislativas, em âmbito estadual.

O presidente da República deve, portanto, editar medidas provisórias apenas em situações emergenciais para suprir necessidade inadiável ou evitar grave dano ao país. Esse ato normativo, como lamentavelmente vem sendo, nunca deve ser utilizado como regra no processo legislativo.

Atribui-se, assim, ao Congresso Nacional, no pleno exercício de suas funções e missões constitucionais, rejeitar MP sempre que não seja considerada relevante ou urgente por aquele poder, exercendo-se o controle político e jurídico em relação à MP e devendo rejeitá-la quando ferir a Carta Política ou quando reputada MP mostrar-se inoportuna ou inconveniente.

Finalmente, cabe ao poder Judiciário suspender a vigência de uma MP ao declarar a inconstitucionalidade desta sempre que, uma vez provocado, constatar a inobservância de requisitos constitucionais que justificam a sua edição.

A República Federativa do Brasil constitui-se em Estado Democrático de Direito, pelo que deve obediência à Constituição de 1988. Para que as medidas provisórias sejam realmente exceção legiferante, cabe não só ao Congresso Nacional e ao poder Judiciário proceder para desativar uma MP, mas também cabe à sociedade brasileira, no exercício de seus direitos civis e políticos, exercerem controle sobre a atuação governamental, especialmente em relação à edição de medidas provisórias, porque o destinatário final das implicações e efeitos diretos e indiretos de uma MP, portanto, é o povo brasileiro.

\section{REFERÊNCIAS}

BALERA, Felipe Penteado. Medida Provisória: o controle dos requisitos constitucionais de relevância e urgência pelo Congresso Nacional e pelo STF. Revista Brasileira de Direito Constitucional - RBDC, n. 14, jul./dez. 2009. Disponível em: http://www.esdc.com.br/RBDC/RBDC-14/RBDC-14-025Artigo_Felipe_Penteado_Balera_(Medida_Provisoria).pdf. Acesso em: 23 fev. 2019.

BRASIL. Constituição Federal. Constituição da República Federativa do Brasil de 1988. Disponível em: http:// www.planalto.gov.br/ccivil_03/constituicao/constituicaocompilado.htm. Acesso em: 24 fev. 2019.

BRASIL. Secretaria de Comunicação Social. Manual de redação: Agência Senado, Jornal do Senado. Brasília: Senado Federal, 2015.

BULOS, Uadi Lammêgo. Curso de direito constitucional. 10. ed. São Paulo: Saraiva, 2016.

CLÈVE, Clèmerson Merlin. Atividade legislativa do poder executivo. 3. ed. São Paulo: Revista dos Tribunais, 2011. DI PIETRO, Maria Sylvia Zanella. Direito administrativo. 32. ed. São Paulo: Forense, 2019.

FERRAZ JÚNIOR. Tércio Sampaio. Introdução ao estudo do direito: técnica, decisão, dominação. 6. ed. São Paulo: Atlas, 2010. 
MEIRELLES, Hely Lopes. Direito administrativo brasileiro. 43. ed. São Paulo: Malheiros, 2017.

MELLO, Celso Antônio Bandeira de. Curso de direito administrativo. 33. ed. São Paulo: Malheiros, 2018.

MORAES, Alexandre de. Direito constitucional. 31. ed. São Paulo: Atlas, 2015.

PORTAL DA LEGISLAÇÃO GOVERNO FEDERAL, 2015. Disponível em: http://www4.planalto.gov.br/legislacao. Acesso em: 20 fev. 2019.

TEMER, Michel. Elementos de direito constitucional. 23.ed. São Paulo: Malheiros, 2010.

TOURINHO, Rita. A discricionariedade administrativa perante os conceitos jurídicos indeterminados. Revista Eletrônica de Direito do Estado (REDE), Salvador: Instituto Brasileiro de Direito Público, n. 15, jul./ago./set. 2008. Disponível em: http://www.direitodoestado.com.br/rede.asp. Acesso em: 22 fev. 2019. 